\title{
KOMUNIKASI KESEHATAN PERILAKU HIDUP SEHAT \#JSR DI MEDIA SOSIAL
}

\author{
Hindina Maulida*, R. Yogie Prawira W, Meydora Cahya Nugrahenti \\ Universitas Tidar \\ Email: hindina@untidar.ac.id
}

\begin{abstract}
ABSTRAK
Untuk meyakinkan masyarakat agar menjalankan perilaku hidup sehat bukan hal yang mudah sehingga perlu menggunakan pendekatan khusus, salah satunya adalah komunikasi kesehatan. Tujuan penelitian adalah untuk mengkaji komunikasi kesehatan perilaku hidup sehat \#JSR yang dilakukan oleh dr. Zaidul Akbar melalui media sosial. Metode penelitian yang digunakan berupa kualitatif deskriptif, yaitu lebih fokus kepada 'apa' daripada 'bagaimana' dan 'mengapa' sesuatu terjadi. Data diperoleh dari hasil wawancara dengan pengguna \#JSR yang aktif menyimak, mengikuti, dan subscribe kajian dr. Zaidul Akbar di media sosial serta observasi di media sosial resmi, seperti akun instagram @ zaidulakbar, channel YouTube dr. Zaidul Akbar Official dan facebook @ officialdrzaidulakbar. Hasil penelitian menemukan 1) Sumber dalam komunikasi kesehatan perilaku hidup sehat \#JSR adalah dr. Zaidul Akbar yang juga sekaligus sebagai penggagasnya, 2) Pesan yang disusun menarik perhatian dengan disertai gambar, pesannya jelas dan relevan, mencantumkan manfaat menerapkan perilaku hidup sehat \#JSR, kerugian bagi yang tidak melaksanakan, menggugah sisi emosional dan rasional, konsisten dan transparan, serta mengandung ajakan untuk bertindak, 3) Media yang digunakan adalah platform media sosial YouTube, Instagram, dan Facebook sebagai media sosial dengan empat peringkat tertinggi yang paling banyak digunakan oleh orang Indonesia, 4) Efek pada penerima pesan berupa efek kognitif, afektif dan behavioral.
\end{abstract}

Kata kunci: JSR, komunikasi kesehatan, media sosial, zaidul akbar

\begin{abstract}
Convincing people to have a healthy lifestyle is not easy, so it needs a particular approach, such as health communication. The study aims to examine health communication \#JSR healthy lifestyle conducted by Dr. Zaidul Akbar through social media. The research method used in the study is descriptive qualitative, which is more focused on 'what' rather than 'how' and 'why' something happens. Data were obtained from interviews with \#JSR users who actively listened, followed, and subscribed to studies of Dr. Zaidul Akbar on social media and observation on the official social media Dr. Zaidul Akbar, like the @zaidulakbar Instagram account, Dr. YouTube channel. Zaidul Akbar Official and Facebook@officialdrzaidulakbar. The results suggest that the source of healthy lifestyle \#JSR is dr. Zaidul Akbar. Second, the message designed to grab audience attention with the picture attached, clear and relevant, provide benefit and risk information, arouse emotional and rational, consistent and transparent, and contain a call to action. Third, the media used are social media platforms, YouTube, Instagram, and Facebook, as social media with the
\end{abstract}


four highest ranks that are most widely used by Indonesians. Fourth, effects on message recipients in the form of cognitive, affective, and behavioral effects.

Keywords: JSR, health communication, social media, zaidul akbar

\section{PENDAHULUAN}

Perilaku individu berkontribusi signifikan dalam menentukan panjang umur seseorang (Parvanta \& Bass, 2020). Schroeder \& Fry (2007) menegaskan bahwa sebanyak 40\% kematian di U.S. disebabkan oleh perilaku individu, seperti makanan yang dikonsumsi, perilaku merokok, aktifitas seksual dan reproduksi, kecepatan mengemudi, dan kurangnya aktifitas fisik (Parvanta \& Bass, 2020). Permasalahan serupa juga menjadi tantangan yang serius di Indonesia, sehingga Kementrian Kesehatan Republik Indonesia mencanangkan Gerakan Masyarakat Hidup Sehat (Germas). Tujuannya adalah untuk merubah perilaku hidup masyarakat yang serba modern dan instan.

Implementasi Germas sebagai sebuah tindakan yang sistematis dan terencana nampaknya masih dalam tahapan marketing (Yen, 2018). Output Germas secara nasional belum tercapai (Cokroadhisuryani, 2018) karena beberapa faktor, seperti kurangnya pengetahuan, kesadaran, sikap, dan perilaku mengenai pola hidup sehat (Dwi, 2018 \& Suryani et al, 2019) yang tercermin dalam rendahnya konsumsi buah dan pengecekan kesehatan secara berkala (Tedy et al., 2018). Perubahan perilaku bukanlah hal yang mudah sehingga dibutuhkan lebih dari sekedar pengingat untuk membuat orang mau berubah dari perilaku tidak sehat menjadi sehat.

Schiavo (2007) dalam bukunya Health Communication: From Theory To Practices juga menjelaskan bahwa untuk meyakinkan masyarakat agar menjalankan perilaku hidup sehat bukanlah hal yang mudah sehingga perlu menggunakan pendekatan khusus salah satunya adalah komunikasi kesehatan. Komunikasi kesehatan adalah studi penggunaan strategi komunikasi untuk menginformasikan dan mempengaruhi pengetahuan, sikap dan praktek kesehatan dan perawatan kesehatan kepada individu maupun komunitas yang akan meningkatkan kualitas kesehatan (Thomas, 2006 \& Schiavo, 2007).

Dalam membangun kebutuhan pada pendekatan komunikasi kesehatan, diperlukan pemahaman yang mendalam tentang persepsi, keyakinan, sikap, perilaku dan hambatan yang dimiliki oleh khalayak sasaran beserta konteks budaya, sosial dan lingkungan tempat tinggalnya. Hal tersebut penting mengingat komunikasi kesehatan adalah bagian dari kehidupan sehari-hari (Du Pré dalam Schiavo, 2007). Sehingga dalam penyampaiannya pun juga menggunakan bahasa dan media yang digunakan oleh banyak orang. Sebagaimana yang diterangkan oleh (Burke \& Barker, 2014) bahwa kajian komunikasi dan promosi kesehatan seringkali fokus pada pesan dan media dengan tujuan untuk memengaruhi perubahan perilaku individu

dr. Zaidul Akbar merupakan salah satu orang yang menggunakan media kekinian untuk mengajak masyarakat merubah perilaku hidup sehat, sehingga perilaku hidup sehat \#JSR yang dipopulerkannya menjadi viral (Prawira W \& Maulida, 2020). \#JSR pada intinya adalah kembali ke kesehatan Alquran dan Sunnah Baginda Rasulullah diganti supaya tidak terlalu umum dan bahasanya dikemas dengan yang sedikit bergaya milenial. Beberapa konsepnya utamanya adalah perilaku hidup sehat yang tak lepas dari konsumsi produk Allah, seperti sayur, buah, aneka tanaman herbal dan perilaku hidup yang sesuai dengan tuntunan Al Qur'an dan Sunnah. 
Trendingnya perilaku hidup sehat \#JSR bagi masyarakat Indonesia terlihat dari banyaknya informasi tentang \#JSR di media sosial. Di instagram misalnya, jika dituliskan \#JSR di kolom pencarian maka akan ditemukan lebih dari 1 juta kiriman tentang topik terkait. Tingginya minat masyarakat tentang perilaku hidup sehat \#JSR dapat dilihat dari banyaknya akun di instagram dengan nama yang hampir serupa seperti @ resep.jsr, @jsr.resep, dr.zaidulakbar_jsr dan sebagainya. Tidak hanya di media sosial, kajian dan seminar tentang perilaku hidup sehat \#JSR juga banyak diadakan di berbagai tempat baik di dalam negeri maupun di luar negeri dengan mendatangkan penggagasnya (Prawira W \& Maulida, 2020).

Fakta tersebut menunjukkan bahwa perilaku hidup sehat \#JSR telah mampu menarik dan mempengaruhi sebagian masyarakat untuk melaksanakan pola hidup sehat (Prawira W \& Maulida, 2020). Parvanta \& Bass (2020) memaparkan bahwa komunikasi kesehatan sangat mungkin merubah perilaku seseorang, namun membutuhkan waktu, strategi dan pendekatan tertentu. Merujuk pada uraian sebelumnya, maka penelitian ini mengkaji komunikasi kesehatan perilaku hidup sehat \#JSR yang dilakukan oleh dr. Zaidul Akbar melalui media sosial.

\section{METODOLOGI PENELITIAN}

Metode penelitian yang digunakan dalam penelitian adalah kualitatif deskriptif, yaitu penelitian yang berupaya untuk mendeskripsikan sebuah fenomena dan karakteristiknya. Penelitian deskriptif lebih fokus kepada 'apa' daripada 'bagaimana' dan 'mengapa' sesuatu terjadi. Salah satu teknik yang sering digunakan untuk mengumpulkan data adalah wawancara dan observasi (Gall, M., Gall, J., \& Borg, 2007). Data dalam penelitian diperoleh dari hasil wawancara dengan pengguna \#JSR yang aktif menyimak, mengikuti, dan subscribe kajian dr. Zaidul Akbar di media sosial. Selain itu juga dilakukan pengamatan pada unggahan di media sosial resmi dr. Zaidul Akbar, seperti akun instagram @zaidulakbar, channel YouTube dr. Zaidul Akbar Official dan facebook @ officialdrzaidulakbar. Unggahan yang diamati berupa foto, story, video, maupun ulasan dalam bentuk kata-kata serta komentar atau interaksi dengan pengikutnya. Data yang ditemukan kemudian dideskripsikan dan dianalisis berdasarkan komponen-komponen komunikasi kesehatan yang terdiri dari sumber, pesan, media, dan efek penerima pesan.

\section{HASIL DAN PEMBAHASAN}

Komponen komunikasi kesehatan tak berbeda halnya dengan komponen komunikasi pada umumnya. yaitu sumber, pesan, media, khalayak, dan permasalahan yang menjadi perhatian utama masyarakat (Laranjo, 2016).

\section{Sumber Komunikasi Kesehatan Perilaku Hidup Sehat \#JSR}

Sumber adalah pihak yang mengirim pesan ke pihak lain. Sumber dalam komunikasi kesehatan perilaku hidup sehat \#JSR adalah dr. Zaidul Akbar yang juga sekaligus sebagai penggagasnya. Dalam proses komunikasi, sumber memiliki peranan yang cukup penting untuk menghasilkan komunikasi yang efektif. Sebagaimana yang dijelaskan dalam teori perubahan perilaku kesehatan, informasi yang disampaikan secara efektif dapat merubah niat/kemauan seseorang sehingga dapat merubah perilakunya (Burke \& Barker, 2014). Perubahan perilaku dan sikap khalayak ditentukan oleh kemampuan sumber (Laranjo, 2016).

Kemampuan sumber adalah kapasitas fisik dan psikologis individu yang mencakup pengetahuan dan keterampilan yang dimiliki. Secara fisik sumber memiliki tubuh yang proporsional, bersih, rapi, dan kulit yang bercahaya sehingga ia menarik dimata khalayak dan memiliki daya persuasi. Sedangkan secara psikologis, sumber memiliki daya persuasi yang sangat besar karena memiliki 
popularitas yang tinggi terkait dengan perilaku hidup sehat \#JSR. Nama dr. Zaidul Akbar tidak dapat dipisahkan dari \#JSR karena keduanya saling berkaitan terutama ketika membicarakan perilaku hidup sehat yang merujuk pada Al Qur'an dan Sunnah.

Popularitasnya dapat dilihat dari jumlah followers di akun instagram resminya yang terus menerus meningkat dan saat ini mencapai lebih dari 2 juta orang. Sedangkan subscriber di YouTube mencapai 26,5k subscriber, jumlah yang mengikuti di facebook sebanyak 10.163 dalam kurun waktu hanya 2 bulan, yaitu sejak dibuat pada tanggal 26 Februari 2020. Begitu juga dengan kajian - kajian tatap muka yang diadakan oleh berbagai pihak baik di dalam maupun luar negeri dengan tema seputar perilaku hidup sehat \#JSR. Disamping itu popularitasnya juga bisa dilihat dari banyaknya nama akun di media sosial yang mengatasnamakan dirinya, seperti @zaidulakbarr_resep, @dr.zaidulakbar_resepjsr, @zaidulakbar.id, @ zaidulakbarfanbase dan masih banyak lagi yang lainnya.

Bila merujuk pada penelitian (Prawira W et al., 2012) maka Dr. Zaidul Akbar dalam konteks ini dapat pula disebut sebagai brand ambassador karena dianggap mewakili \#JSR dengan visibility yang tinggi. Visibility adalah popularitas yang melekat pada sumber yang mewakili produk yang dibawanya. Sumber dengan popularitas yang tinggi akan lebih mudah untuk mempersuasi khalayak dalam mengambil keputusan. Dalam hal ini keputusannya dapat berupa sikap, ataupun perilaku untuk melaksanakan perilaku hidup sehat \#JSR. Sedangkan dari segi kredibilitas, sumber memiliki pengetahuan dan keterampilan yang handal mengenai perilaku hidup sehat \#JSR. Hal ini terlihat dari kemampuannya menyampaikan informasi yang komprehensif tentang konsep utama \#JSR, manfaat melaksanakan \#JSR, resep untuk keluhan atau penyakit-penyakit tertentu disertai dengan khasiat dari bahan-bahan yang dianjurkan.

Seperti yang diungkapkan oleh (Bylund \& Peterson, 2014) bahwa dokter yang memiliki keterampilan dalam menyampaikan informasi berkontribusi terhadap kepuasan dan keterpercayaan penerima pesan. Hal demikian terjadi karena khalayak perlu mempercayai komunikator sebelum mengadopsi tindakan atau kepercayaan yang baru diperolehnya (Parvanta \& Bass, 2020). Kemampuan sumber untuk menjawab pertanyaan followers serta diundangnya beliau sebagai pembicara utama diberbagai kajian \#JSR merupakan bentuk kredibilitas yang dimiliki dr. Zaidul Akbar. Dengan latar pendidikan kedokteran umum dari Universitas Diponegoro serta pekerjaannya sebagai dokter yang telah praktik diberbagai rumah sakit selama lebih dari 10 tahun menjadikan dokter Zaidul akbar dianggap memiliki keahlian yang mumpuni sebagai seorang sumber perilaku hidup sehat.

Pemaparan tersebut menunjukkan bahwa dr. Zaidul Akbar adalah sumber yang kredibel dimata khalayak, sebagaimana penelitian (Prawira W \& Maulida, 2020) bahwa terdapat korelasi yang kuat antara kredibilitas Zaidul Akbar dengan sikap followers akun instagram @zaidulakbar mengenai perilaku hidup sehat JSR. Crosswell et al., (2018) menyatakan hal serupa bahwa keberhasilan komunikasi tergantung kepada seberapa terpercaya dan kredibel dipersepsi oleh khalayak. Disamping itu, kredibilitas sumber berkontribusi pula terhadap penerimaan kredibilitas pesan.

\section{Pesan Komunikasi Kesehatan Perilaku Hidup Sehat \#JSR}

Burke \& Barker (2014) menjelaskan bahwa kajian komunikasi dan promosi kesehatan seringkali fokus pada pesan dan media karena tujuannya adalah untuk memengaruhi perubahan perilaku individu. Pesan adalah perpaduan simbol-simbol dan kata-kata yang diharapkan oleh sumber untuk ditransmisikan ke penerima pesan atau dengan kata lain pesan berkaitan dengan apa isi yang ingin disampaikan ke khalayak. WHO dalam Effective Communications Participant Handbook menjelaskan bahwa produk komunikasi kesehatan masyarakat harus memenuhi tujuh kriteria agar 
pesannya efektif, yaitu command attention, clarify the message, communicate a benefit, consistency, cater to heart and the head, create trust dan call to action (WHO, 2015).

Command attention adalah pesan yang disampaikan harus berupa isu yang singkat, jelas, fokus dengan argumen yang menggunakan fakta dan gambar emotif yang menarik khalayak (WHO, 2015). Berdasarkan hasil wawancara dengan informan diketahui bahwa dr. Zaidul Akbar sejak awal fokus membahas tentang perilaku hidup sehat \#JSR mulai dari apa itu \#JSR, bagaimana pola makan, minum, olahraga dan ketentuan beristirahat yang sesuai dan dibutuhkan oleh tubuh. Penjelasannya dibuat secara bertahap dan singkat pada setiap postingan sehingga khalayak dapat dengan mudah memahami pesan yang disampaikan. Sebagaimana pengakuan salah satu informan "...Enak sih liat postingannya mmm berwarna-warni, kadang santai, kadang serius banget, kadang jleb banget, trus per postingan yang dibahas ya cuma satu resep... misal resep buat batuk aja, ga semua langsung dimasukin...".

Petikan wawancara menunjukkan bahwa postingan sumber sangat jelas bagi khalayak dan tidak membuat bingung karena setiap unggahan di facebook dan instagram hanya membahas satu poin seperti yang disebutkan. Newson (dalam Kauppi, 2015) menyebutkan bahwa pesan harus dapat dipahami dan simpel. Huo \& Turner (2019) dengan mengadopsi dari European Centre for Disease Prevention and Control: Health Communication menambahkan bahwa pesan harus dapat dimengerti dengan bahasa yang mudah bagi khalayak. Dalam memaparkan konsepnya, dr. Zaidul Akbar dikatakan juga sering membagikan hasil penelitian ilmuwan barat meskipun menurutnya kadang hanya dibaca sekilas atau hanya captionnya saja.

Selain argumentasi yang rasional dan ilmiah, dr. Zaidul Akbar dalam mentrasmisikan pesan \#JSR tidak hanya dalam bentuk kata-kata tetapi juga disertai dengan gambar-gambar yang emotif sehingga dapat menarik khalayak. Thompson (2014) dalam bukunya yang berjudul The Essential Guide to Public Health and Health Promotion menuliskan bahwa untuk mendapatkan perhatian khalayak, maka pesan dapat ditambahkan dengan gambar. Informasi yang disertai gambar lebih cepat diproses, diterjemahkan, dipertahankan, diakses dari ingatan, serta dapat memperoleh reaksi emosi yang lebih kuat (Rus \& Cameron, 2016).

"awalnya dikasih tahu temen, trus pas lihat IGnya scroll scroll lihat gambarnya tuh kaya wah kok seger kayanya, bikin enak badan nih. Ya udah aku coba-coba ikut 7 days challenge. Akhirnya ketagihan deh, meskipun kadang suka cheating sih ha..ha..ha...

Gambar emotif adalah gambar yang memunculkan respon emosional dari pembaca seperti terkejut, senang, sedih, takut, dan sebagainya. Seperti yang dituliskan oleh (Passalacqua, 2014) dari buku Health Communication Message Design: Theory and Practice bahwa untuk mencapai tujuan berupa perubahan perilaku, maka pesan kesehatan harus di desain menarik dan mendapat perhatian khalayak. Millar (2005) dalam kajiannya menyebutkan bahwa pesan yang tidak menarik, tidak akan mampu merubah sikap dan perilaku seseorang. Hal ini disebabkan karena individu yang tidak tertarik, tidak akan memperhatikan apalagi mengingat pesan yang diberikan. Oleh karenanya sangat kecil kemungkinan untuk dapat terpersuasi, sehingga pesan yang menarik memiliki peran penting dalam proses tersebut.

Clarify the message adalah pesan yang efektif harus dapat memberikan informasi yang relevan seperti siapa yang beresiko, apa kerugian yang diperoleh bila tidak melakukannya dan bagaimana melakukannya (WHO, 2015). Menurut penelitian, individu yang mendapatkan informasi sehingga mengetahui dirinya beresiko, biasanya akan melakukan, mengadopsi dan mempraktikkan pesan yang diterimanya sebagai langkah proteksi untuk mencegah terjadinya resiko (Bowen \& $\mathrm{Li}, 2018$ dan Rus \& Cameron, 2016). Namun apabila pesannya tidak mengindikasikan bahaya atau kerugian 
bagi dirinya, individu cenderung untuk mengabaikan pesan yang diterimanya dan tidak merubah perilakunya (Godinho et al., 2015).

Selanjutnya, unggahan akun instagram @zaidul akbar memberikan pula informasi tentang siapa yang harus menggunakan resep yang diberikan, bagaimana aturan pakainya serta prosedur menjalankannya, "Cukup jelas sih, step-stepnya trus kadang juga kalo video suka dikasih link ke YouTube. Nah itu lebih jelas kadang suka ada demo masaknya. Selain menjelaskan di postingan instagram dan facebook, dr. Zaidul Akbar juga sering mencantumkan link yang menghubungkan ke YouTube untuk informasi yang berupa cuplikan video.

Di akun YouTube, terdapat video yang lebih panjang dan komprehensif mulai dari penyebab penyakit, cara pencegahan, resep-resep untuk mencegah dan mengobati, manfaat serta konsekuensinya bila tidak dilaksanakan dengan dilengkapi tata cara dan aturannya. Teori pembelajaran media menyebutkan bahwa multimedia yang mengkombinasikan gambar, audio, dan teks informasi akan mengoptimalkan pemahaman, keterlibatan serta proses pembelajaran (Rus \& Cameron, 2016). Lebih lanjut, Gough et al., (2017) mengatakan, adanya video dapat memberikan pemahaman yang lebih mendalam pada persepsi, sikap, perubahan perilaku.

Selain prosedur dan aturan konsumsi, postingan dr. Zaidul Akbar memberikan catatan-catatan untuk beberapa orang yang memiliki penyakit tertentu baik secara langsung maupun di dalam kolom komentar ketika yang menanyakan. Keterangan tersebut memudahkan pengikut akun media sosialnya untuk melakukan atau mempraktekkan resep yang dibagikan. Godinho et al., (2015) mengutarakan bahwa pesan kesehatan lebih tepat disampaikan dengan desain pesan yang mengutarakan resiko dan manfaat positif dari sebuah perilaku kesehatan.

Communicate a benefit adalah pesan yang disampaikan harus secara eksplisit menyebutkan manfaat yang akan diperoleh khalayak (WHO, 2015). Sebagaimana pemaparan sebelumnya bahwa penjelasan dr.zaidul akbar menyebutkan secara langsung manfaat dari tantangan 30 hari minum air putih sebagai salah satu bentuk perilaku hidup sehat. Menjelaskan manfaat yang akan diperoleh dalam pesan kesehatan diakui lebih disukai oleh khalayak dibandingkan dengan pesan yang menyatakan kerugian sebagai akibat tidak mengadposi perilaku kesehatan tertentu (Viswanath \& Emmons, 2006).

Consistency adalah pesan harus konsisten baik itu secara data maupun fakta karena konsistensi pesan merupakan salah satu aspek determinan dari persepsi dan perilaku khalayak (WHO, 2015 dan Bowen \& Li, 2018). Sehingga pesan yang tidak konsisten akan dengan sangat cepat merusak kepercayaan publik terhadap reputasi dan kredibilitas sumber. Berdasarkan hasil wawancara, dr. Zaidul akbar dianggap konsisten dengan informasi kesehatan dan perilaku hidup sehat \#JSR baik di media sosial maupun waktu tatap muka. Sedangkan di media sosial, misalnya dr. Zaidul Akbar ketika memberikan resep \#JSR tentang menstruasi pada wanita maka data dan informasinya tidak pernah saling bertentangan antara postingan lama maupun baru.

Bowen \& Li (2018) menuturkan bahwa konsistensi penyampaian informasi akan membuat komunikasi efektif karena pesan dilakukan secara terus-menerus dan diulangi berkali-kali sehingga individu lebih paham dan mempercayai resiko yang ditimbulkan sehingga terdapat kepercayaan kepada sumber maupun informasi yang diberikan. Persepsi demikian dapat lebih mudah mendorong khalayak untuk mengadposi perilaku kesehatan yang disampaikan, sebagaimana yang dituliskan oleh (Corcoran, 2007) bahwa pengulangan secara signifikan dapat mempengaruhi tindakan komunikasi.

Cater to heart and the head adalah pesan harus menyentuh sisi emosional khalayak karena orang mendengarkan dengan telinga, mata dan hati (WHO, 2015). Apabila sebuah pesan dapat masuk ke 
hati seseorang maka terdapat kemungkinan yang besar bahwa pesan didengarkan, dimengerti, dan dilakukan sehingga memicu untuk bertindak atau berubah. Pesan yang emosional biasanya berupa pesan yang disertai dengan gambar yang menarik seperti yang terlihat pada penjabaran sebelumnya. Gough et al., (2017) dalam hal ini menyatakan bahwa gambar selain menarik perhatian juga menggugah emosi dan motivasi.

Postingan lain yang juga melibatkan sisi emosional adalah cerita dari pelaku \#JSR baik tentang permasalahan kesehatan yang dialami, perjuangan maupun keberhasilannya. Edgar \& Volkman (2012) menyimpulkan bahwa berbagi cerita dapat menambah kredibilitas dan otensitas pesan kesehatan. Berdasarkan pengamatan di media sosial dan wawancara, pesan dr. Zaidul Akbar tidak hanya menggugah sisi emosional, namun terdapat argumentasi yang rasional berupa penjelasan dari penelitian ilmiah. Seperti yang diungkapkan oleh O'Keefe (dalam Harrington, 2015) bahwa pesan kesehatan harus berdasarkan bukti, terutama untuk orang-orang yang masih dalam tahapan persiapan (Nabi, 2015).

Create trust adalah pesan harus dapat dipercaya kebenarannya dengan menggambarkan situasi yang sebenarnya, adanya transparansi, perhatian, dan empati (WHO, 2015). Selain pesannya yang akurat dengan didukung bukti penelitian serta konsisten dalam penyampaiannya, dr Zaidul Akbar juga dapat membangun kepercayaan pada pesan yang diutarakan. Sebagaimana yang disampaikan oleh narasumber "Percaya...percaya saya soalanya beliaunya kan dokter jadi gak mungkin ngebohong, apalagi sering kan dipraktekin di YouTube IG juga ada".

dr. Zaidul Akbar menumbuhkan rasa percaya pada khalayak dengan memperlihatkan kejujuran perilaku sehari-harinya yang di posting di di media instagram seperti saat memperagakan makan tempe mentah, makan sayur mentah dan meminum minuman rimpang yang dibuatnya. Disamping itu untuk menjaga kepercayaan masayarakat, sumber juga mengunggah postingan tentang untuk mereport akun-akun yang mengatasnamakan dirinya yang bertujuan komersial. Menurut Bowen \& Li (2018) kepercayaan publik dapat diperoleh dengan adanya transparansi. dr Zaidul Akbar memberikan transparansi dalam menyampaikan informasi, misalnya ketika menyampaikan khasiat rimpang yang bisa meningkatkan imun dan semoga terhindar COVID-19. Sumber menjelaskan kondisi sebenarnya dengan hanya memaparkan manfaatnya dan tidak mengklaim bahwa dengan minum rimpang akan terhindar atau bahkan menyembuhkan pasien COVID-19.

Faktor lain yang berkontribusi terhadap kepercayaan khalayak adalah empati dan perhatian (Degutis \& Babcock-Dunning, 2011). Bentuk perhatian dan empati sumber \#JSR di akun media sosial adalah membagikan cerita orang-orang yang berhasil, sembuh dari penyakit, memberikan motivasi dan doa bagi orang yang sedang berjuang. Selanjutnya, empati dan perhatian menurut penelitian merupakan komponen yang secara positif meningkatkan kepuasan pasien sehingga menumbuhkan kepercayaan (Lan \& Yan, 2017).

Call to action adalah pesan harus dapat mendorong khalayak untuk bertindak (WHO, 2015). Unggahan dr. Zaidul Akbar bukan hanya dalam bentuk pemaparan, namun disertai pula dialog, reminder, motivasi, dorongan dan ajakan untuk berubah. Ajakannya untuk melaksanakan perilaku hidup sehat yang kembali ke Al Qur'an dan Sunnah dan agar terhindar dari penyakit. Sebagaimana yang disampaikan oleh The Surgeon General, U.S. Department of Health And Human Services bahwa call to action fokus pada promosi optimalisasi kesehatan sebelum terserang penyakit (U.S. Department of Health and HumanServices, 2009). Guo \& Bian (2019) menyebutkan bahwa pesan kesehatan yang disampaikan melalui media sosial tidak hanya berupa pesan edukasi, diskusi, pengingat, umpan balik tetapi juga motivasi dan ajakan untuk berpartisipasi dan berperilaku sehat dengan memaparkan bukti-bukti keberhasilan. 


\section{Media Komunikasi Kesehatan Perilaku Hidup Sehat \#JSR}

Media adalah perangkat yang digunakan untuk menyampaikan pesan dari sumber kepada khalayak yang mengindikasikan tentang bagaimana proses penyampaian atau apa yang menghubungkan sumber dengan khalayak (Mitu, 2016). Perkembangan teknologi komunikasi dan informasi memberikan pilihan media baru yang dapat digunakan oleh sumber untuk menyampaikan informasi kepada masyarakat, yaitu internet. Keunggulan media baru ini berupa daya jangkau yang luas, masif dan cepat, update informasi yang mudah, potensi interaksi untuk pemahaman yang mendalam serta adanya retensi informasi.

Berdasarkan data yang dirilis oleh We Are Social dan Hootsuite dalam Digital 2020 Report, jumlah pengguna internet di Indonesia termasuk salah satu yang tertinggi di dunia. Tercatat sampai bulan Januari 2020, ada 175,4 juta pengguna atau sekitar $64 \%$ dari penduduk Indonesia merupakan pengguna internet. Jumlahnya meningkat sekitar 25 juta pengguna (17\%) dari tahun 2019 dengan waktu rata-rata mengakses hampir 8 jam per hari. Data tersebut menunjukkan bahwa hampir setengah populasi Indonesia menghabiskan 1/3 waktunya dalam sehari untuk mengakses internet baik untuk berkomunikasi ataupun untuk mencari informasi yang dibutuhkan (Kemp, 2020).

"saya tahunya dari temen, awalnya yang saya kira minum infuse water, eh ternyata enggak. Bukan infuse water tapi JSR, coba aja googling gitu katanya ... ya udah saya searching-searching, baca-baca eh ada IGnya juga.

Informan di atas menuturkan bahwa dirinya mengetahui \#JSR setelah melakukan pencarian di internet, meskipun terminologi \#JSR diperoleh dari temannya. Dari internet, informan kemudian menemukan bahwa penggagas perilaku hidup sehat \#JSR membagikan informasinya melalui media sosial instagram. Selain instagram, dr. zaidul akbar juga menggunakan media sosial lain seperti YouTube dan facebook. Penggunaan platform media sosial oleh dr.Zaidul Akbar merupakan langkah yang tepat karena YouTube, instagram, dan facebook merupakan media sosial yang paling banyak digunakan oleh orang Indonesia (Kemp, 2020). Anand et al., (2013) menguraikan bahwa media memainkan peran penting dalam menginformasikan berbagai aspek kehidupan individu, termasuk akses ke informasi kesehatan.

Hal ini di dukung dengan data We Are Social dan Hootsuite yang mengumumkan bahwa 65 persen pengguna internet di Indonesia mengunakan ponsel dibanding perangkat lain dengan durasi sekitar 5 jam. Adapun $80 \%$ (sekitar 4 jam) dari penggunaan internet melalui ponsel digunakan untuk mengakses media sosial (Kemp, 2020). Maka dapat dikatakan bahwa media sosial seolah menjadi kebutuhan sehari-hari dimana orang rela mengesampingkan kebutuhan lainnya untuk memastikan bahwa kuota untuk mengakses media sosial ada (Simon Kemp, 2011). Dengan demikian, media sosial merupakan media yang potensial untuk menyampaikan informasi kesehatan di Indonesia. Kim (2018) menyebutkan bahwa media sosial telah menjadi jalur penting dalam penyampaian dan pertukaran informasi atau konten kesehatan dengan kemampuannya berupa jangkauan khalayak yang luas ke berbagai kelompok populasi, tanpa memandang usia, pendidikan, ras atau etnis, dan lokalitas, dibandingkan dengan metode komunikasi tradisional.

Adams (2016) memperkuat bahwa berbagai jenis media sosial dapat digunakan untuk berbagai tujuan dan skala jangkauan ke audiens potensial, kecepatan berbagi informasi dan tanggapan, serta kemudahan menggabungkan berbagai format informasi (yaitu, teks, gambar, video). Oleh karenanya media sosial dianggap menguntungkan untuk mendistribusikan dan mengumpulkan informasi tentang kesehatan, perawatan, dan praktik sehat. Dalam membagikan postingan via instagram dan facebook, dr Zaidul Akbar tidak hanya berupa teks tetapi juga ada gambar, cuplikan video. Disamping itu, media sosial memberikan peluang pasien untuk berinteraksi dengan dokter secara langsung mengenai kondisi kesehatannya secara gratis meskipun terkadang dr. Zaidul Akbar 
tidak membalas langsung komentar pengikut akun media sosialnya karena sudah ada di postingan sebelumnya.

Kesempatan berinteraksi yang disediakan oleh media sosial diakui meningkatkan keterhubungan dan partisipasi langsung dalam proses komunikasi kesehatan (Kim, 2018 dan Sommariva et al., 2018). Kim (2018) mengindikasikan bahwa hal tersebut sesuai dengan hakikat partisipasi media sosial, dimana media ini mempromosikan komunikasi dua arah antara dokter dan anggota audiens. Selain memberikan tanggapan, di media sosial dokter Zaidul Akbar juga sering membagikan testimoni followersnya yang berhasil menggunakan resep \#JSR untuk mengatasi permasalahan kesehatan yang dihadapinya. Postingan seringkali juga direspon oleh pengguna media lain yang akhirnya terjadi interaksi didalamnya. Griffiths et al., (2015) menyebutkan bahwa media sosial merupakan wahana yang memberikan kesempatan beinteraksi secara digital sehingga individu dapat berkomunikasi dengan orang lain yang memiliki permasalahan kesehatan yang sama. Interaksi khalayak pada media sosial cenderung dilakukan untuk mencari dukungan emosional dengan menemukan pengalaman dari orang yang memiliki permasalahan yang sama. sehingga menimbulkan motivasi. Selain dukungan, harapan adalah salah satu alasan pengikut di instagram dan facebook untuk berbagi cerita dan pengalaman hidup yang dimilikinya dimana antar pengikut instagram saling memberikan dukungan satu sama lain (Kim, 2018).

Interaksi di media sosial menurut Flynn \& Stana (dalam Griffiths et al., 2015), juga meminimalisir terjadinya penghakiman dibandingkan dengan interaksi di dunia nyata sehingga individu mau lebih terbuka untuk membicarakan kondisi kesehatannya yang sangat sensitif dan mungkin memalukan. Oleh karenanya tidak mengherankan jika diskusi dan testimoni kesehatan di media sosial lebih berpengaruh dan menginspirasi orang lain dibandingkan berdiskusi dengan petugas medis professional. Kajian tentang media sosial menunjukkan bahwa media sosial memiliki peran yang signifikan dalam menyebarkan resiko perilaku tertentu, dukungan sosial, pengambilan keputusan, perubahan perilaku serta penyediaan edukasi, dan dukungan menagemen diri (Laranjo, 2016)

Penyediaan edukasi, juga dilakukan oleh pengikut \#JSR di media sosial melalui testimoni-testimoni keberhasilan yang dialaminya, atau dialami oleh orang lain. Sehingga muncullah sumber-sumber baru yang disebut dengan receiver sources, yaitu sumber yang menyampaikan informasi perilaku hidup sehat \#JSR berdasarkan informasi yang diperolehnya di media sosial offical dr. Zaidul Akbar. Namun demikian tidak semua receiver source diakui oleh dr. Zaidul Akbar, hanya akunakun tertentu yang dipercayainya. Hal ini terjadi karena banyak oknum-oknum yang tidak bertanggung jawab dan mencari keuntungan semata.

Sedangkan untuk YouTube, dr. Zaidul Akbar menggunakannya untuk menyiarkan kembali kajian yang diadakannya secara tatap muka. Dalam YouTube penjabarannya lebih mendalam, luas, bahanbahan yang ditunjukkan secara langsung, cara mengolahnya dan terkadang dr. Zaidul Akbar juga ada demo secara langsung di kajian. Dilihat dari jangkauan dan aksesibilitas, penggunaan YouTube sebagai media promosi kesehatan \#JSR cukup efektif. Berdasarkan Digital 2020 Report pada bulan Januari YouTube menduduki peringkat pertama platform media sosial yang paling panyak digunakan oleh orang Indonesia (Kemp, 2020).

Efektifitas YouTube sebagai media distribusi pesan kesehatan juga diakui oleh (Prybutok, 2013 dan Guo \& Bian, 2019) dimana platform ini memfasilitasi penerimaan pengetahuan dan perubahan perilaku karena terdapat fasilitas video dan interaksi dan bersosialisasi antar penggunanya. Interaksi antara pengguna di YouTube memiliki peluang yang tinggi untuk dapat mempengaruhi satu sama lain sehingga terjadi perubahan perilaku sehat (Madathil et al., 2015). Meskipun demikian, terdapat beberapa penelitian meragukan YouTube sebagai media yang efektif karena kurangya kredibilitas dan kepercayaan informasi yang disampaikan (Haslam et al., 2019). 
Dalam konteks diseminasi informasi kesehatan \#JSR oleh dr. Zaidul Akbar, YouTube menjadi sarana yang efektif karena informasi disampaikan oleh sumber yang kredibel terlihat dari keahlian, keterpercayaan, dan juga latar pendidikan kedokteran yang dimilikinya. Dengan demikian, informasi yang disampaikan juga dapat dipercaya dan dipertanggungjawabkan seperti halnya pesan yang disampaikan di instagram serta facebook. Sesuai yang disampaikan S. Syed-Abdul et al., (2016) media sosial sebagai platform yang memberikan dimesi baru dalam kesehatan karena menawarkan peluang peningkatan hasil pada kesehatan melalui interaksi antara pasien dengan tenaga kesehatan profesional

\section{Efek Penerima Pesan dalam Komunikasi Kesehatan Perilaku Hidup Sehat \#JSR}

Komunikasi kesehatan merupakan sebuah proses yang panjang, yang dimulai dan diakhiri dengan berdasarkan kebutuhan dan keinginan khalayak (Schiavo, 2007). Sehingga mengetahui efek terpaan pesan dari khalayak merupakan hal yang krusial guna mengetahui keberhasilan komunikasi kesehatan yang dilaksanakan. Westerwick et al., (2017) menjabarkan bahwa salah satu tantangan terbesar dalam komunikasi kesehatan adalah mengubah sikap dan perilaku individu untuk berperilaku hidup sehat karena biasanya orang cenderung untuk menolak pesan yang mengganggu kepercayaan dan perilaku mereka saat ini.

Berdasarkan hasil olah data penelitian, maka diperoleh klasifikasi tentang efek penerima pesan komunikasi kesehatan perilaku hidup sehat \#JSR sebagai berikut:

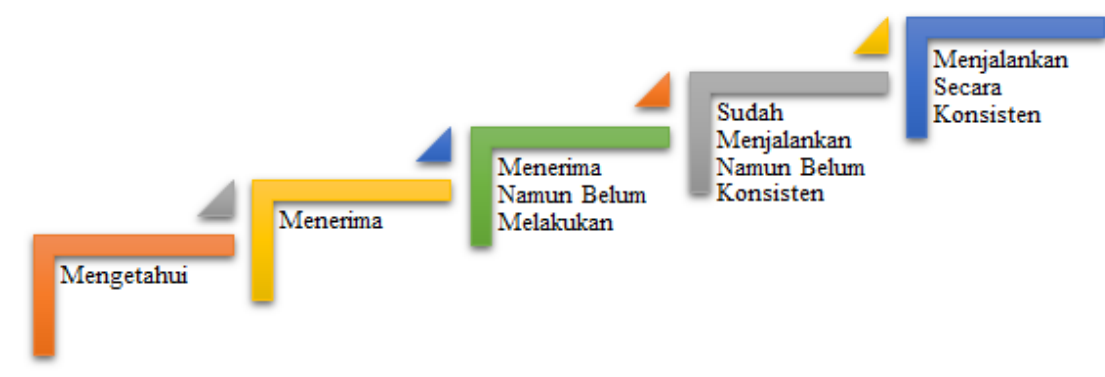

Gambar 1. Klasifikasi efek penerima pesan (Hasil olah data penelitian, 2020).

Pada level pertama diketahui bahwa penerima pesan mengetahui tentang perilaku hidup sehat \#JSR, namun tingkat pengetahuannya berbeda-beda ada yang mengetahui secara detail, namun ada pula yang mengetahui hanya sebatas terminologi, penggagasnya dan konsep utama dari perilaku hidup sehat \#JSR. Level kedua adalah informan yang menerima, yaitu sudah mengetahui perilaku hidup sehat \#JSR beserta manfaatnya, pentingnya bagi tubuh, kebenaran dan penjelasan ilmiahnya serta cerita kemanjuran \#JSR mencegah dan mengobati beberapa permasalahan kesehatan.

Level ketiga adalah narasumber sudah menerima dan mempercayai kebenaran dari perilaku hidup sehat \#JSR namun belum ingin atau belum mampu menjalankannya karena beberapa faktor. Beberapa alasan yang dikemukakan oleh narasumber adalah adanya perasaan belum sanggup meninggalkan junkfood, terbiasa dengan kebiasaan lama, berat karena \#JSR tidak enak, belum sempat karena harus mengolah sendiri, atau karena masih merasa perilaku hidupnya tidak terlalu membahayakan dan belum membutuhkan. Alasan yang sama diakui oleh narasumber yang sudah masuk pada level keempat, yaitu sudah melakukan namun belum konsisten. Maksudnya adalah, narasumber menjalankan \#JSR hanya ketika waktu tertentu seperti saat sedang popular dan fenomenal, saat sedang ada hajat ingin hamil, ada masalah kesehatan pencernaan atau hanya beberapa kali kemudian kembali kebiasaan lama dan begitu seterusnya. Sedangkan pada level 
terakhir, yaitu narasumber yang secara konsisten menjalankan, mengakui ada perubahan, dan merasa senang dengan perilaku hidup sehat yang dijalankan.

Berkaitan dengan efek penerima pesan, (Ardianto et al., 2014) menjelaskan bahwa ada 3 jenis efek, yaitu efek kognitif, efek afektif, dan efek behavioral. Efek kognitif adalah akibat yang muncul pada penerima pesan berupa pengetahuan dan informasi tentang suatu hal. Apabila merujuk pada pemaparan hasil penelitian diatas, maka dapat diketahui bahwa terdapat efek kognitif pada narasumber di semua level yang telah dijabarkan. Bentuk efek kognitifnya adalah pengetahuan dan informasi yang bersumber dari media sosial Instagram, Facebook, ataupun YouTube.

Efek selanjutanya yang lebih tinggi adalah efek afektif, yaitu efek yang berupa munculnya perasaan mengenai informasi yang diperoleh seperti penilaian, penerimaan ataupun penolakan. Efek afektif diperoleh narasumber pada level kedua hingga level kelima karena sudah ada penilaian dan penerimaan mengenai perilaku hidup sehat \#JSR baik tentang manfaatnya, kebenarannya atau urgensi penerapan konsep tersebut. Sedangkan untuk efek terakhir hanya terjadi pada narasumber di level keempat dan kelima, yaitu narasumber yang sudah menjalankan perilaku hidup sehat \#JSR baik yang sudah konsisten maupun yang belum. Hal tersebut merujuk pada definisi efek behavioral sebagai akibat yang timbul pada diri penerima pesan dalam bentuk perilaku, tindakan dan kegiatan (Ardianto et al., 2014).

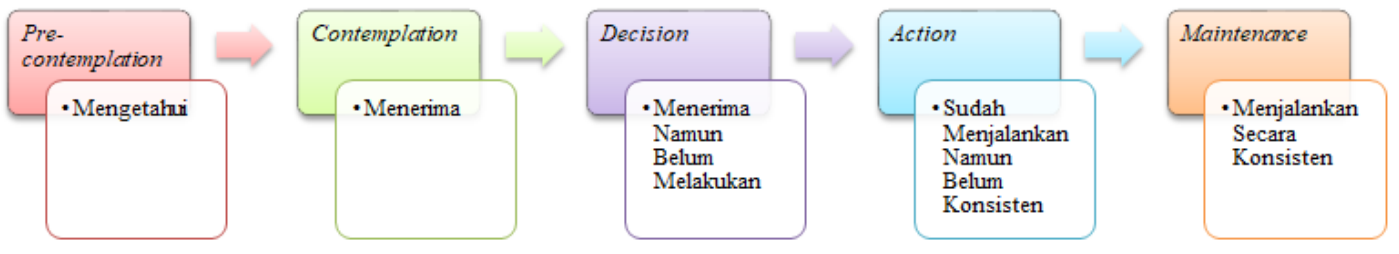

Gambar 2. Model perubahan perilaku yang telah dimodifikasi peneliti (Schiavo, 2007).

Schiavo (2007) dalam bukunya yang berjudul Health Communication: From Theory to Practices menjelaskan model perubahan perilaku pada komunikasi kesehatan menjadi 5 tahapan, seperti yang terlihat dalam gambar sebelumnya. Berdasarkan Model perubahan perilaku diatas, narasumber pada level pertama masih dalam tahap precontemplation yaitu, narasumber belum memiliki keinginan untuk menerapkan perilaku hidup sehat \#JSR namun tidak berhenti untuk membaca informasi yang disebarkan melalui media sosial. Sedangkan narasumber yang menerima pesan perilaku hidup sehat \#JSR atau berada pada level dua, disebut oleh (Schiavo, 2007) berada dalam tahapan contemplation, yaitu individu sedang mempertimbangkan untuk mengadopsi perilaku kesehatan yang direkomendasikan. Dengan kata lain narasumber sedang menimbang apakah mau melaksanakan perilaku hidup sehat \#JSR atau tidak.

Bagi narasumber yang berada pada level 3, yaitu narasumber yang menilai bahwa perilaku hidup sehat yang dipopulerkan dr. Zaidul Akbar benar dan bermanfaat namun belum mau mengadopsi perilakukan berarti sudah masuk dalam tahapan mengambil keputusan. Artinya, narasumber sudah memutuskan untuk menjalankan atau tidak menjalankan pesan kesehatan yang diterimanya. Sementara itu narasumber yang sudah menjalankan namun belum konsisten berada pada tahapan action yaitu sudah terdapat tindakan untuk melaksanakan perilaku hidup sehat \#JSR dalam waktu yang tidak lama. Terakhir, narasumber yang sudah melaksanakan secara konsistena dan dalam jangka waktu yang lama sehingga sudah melekat dalam kesehariannya termasuk dalam tahapan maintenance. 
Berdasarkan pemaparan diatas, maka dapat disimpulkan bahwa setiap individu dapat memperoleh efek yang berbeda-beda dan berada pada tahapan perubahan perilaku yang berbeda tergantung pada faktor-faktor yang mendasarinya, misalnya pengalaman pribadi individu terkait permasalahan kesehatan yang dihadapinya, pengaruh lingkungan atau orang-orang yang dianggap penting, keluarga, pemuka agama, atau publik figur yang dikaguminya.

\section{KESIMPULAN}

Komunikasi kesehatan \#JSR telah memenuhi komponen-komponen proses komunikasi berupa sumber, pesan, media, dan efek pada penerima pesan. Sumber dalam komunikasi kesehatan perilaku hidup sehat \#JSR adalah dr. Zaidul Akbar yang sekaligus penggagasnya. Sumber memiliki pengetahuan dan keterampilan yang handal mengenai perilaku hidup sehat \#JSR. Nama dr. Zaidul Akbar tidak dapat dipisahkan dari \#JSR karena keduanya saling berkaitan terutama ketika membicarakan perilaku hidup sehat yang merujuk pada Al Qur'an dan Sunnah. Pesan yang disampaikan mampu menarik perhatian serta menggugah sisi emosional dan rasional audiens dengan pencantuman gambar, testimoni serta argument yang disertai bukti penelitian ilmiah. Pesan juga jelas dan relevan, mencantumkan keuntungan, kerugian serta resiko, konsisten dan transaparan sehingga menimbulkan kepercayaan, dan terdapat dorongan, ajakan untuk bertindak. Media informasi yang digunakan oleh sumber perilaku hidup sehat \#JSR adalah media sosial Instagram, YouTube, dan Facebook sebagai media sosial yang paling banyak diakses oleh orang Indonesia. Efek pada penerima pesan berupa efek kognitif, afektif, dan behavioral yang diklasifikasikan menjadi lima level yaitu level mengetahui (pre-contemplation), level menerima (contemplation), level menerima namun belum melaksanakan (decision), sudah menjalankan namum belum konsisten (action), dan level terakhir, yaitu sudah menjalankan secara konsisten (maintenance). Bagi penelitian selanjutnya disarankan untuk melakukan penelitian efektifitas pesan dengan metode penelitian kuantitatif.

\section{DAFTAR PUSTAKA}

Adams, S. A. (2016). Use of Social Media by Hospitals and Health Authorities. In Shabbir SyedAbdul, E. Gabarron, \& A. Y. S. Lau (Eds.), Participatory Health Through Social Media (pp. 27-42). UK: Academic Press.

Anand, S., Gupta, M., \& Kwatra, S. (2013). Social Media and Effective Health Communication. International Journal of Social Science \& Interdisciplinary Research, 2(8), 39-46.

Ardianto, E., Komala, L., \& Karlinah, S. (2014). Komunikasi Massa. Bandung: Simbiosa Rekatama Media.

Bowen, S. A., \& Li, J.-Y. (2018). Communication Ethics for Risk, Crises, and Public Health Contexts. In H. D. O'Hair, H. Chapman, \& M. Sizemore (Eds.), Risk and Health Communication In An Evolving Media Environment (pp. 227-248). New York: Routledge.

Burke, N. J., \& Barker, J. C. (2014). Health Communication 'noise' Insights From Medical Anthropology. In H. E. Hamilton \& W. S. Chou (Eds.), The Routledge Handbook of Language and Health Communication (pp. 15-28). New York: Routledge.

Bylund, C. L., \& Peterson, E. B. (2014). The Contribution of Provider-Patient Communication to Health Disparities. In H. E. Hamilton \& W. S. Chou (Eds.), The Routledge Handbook of Language and Health Communication (pp. 586-599). New York: Routledge.

Cokroadhisuryani, H. (2018). Analisis Pelaksanaan Gerakan Masyarakat Hidup Sehat (Germas) Di Wilayah Kerja Puskesmas Ngaglik I [Universitas Islam Indonesia]. https://dspace.uii.ac.id/handle/123456789/6730

Corcoran, N. (2007). Communicating Health: Strategies for Health Promotion. London: Sage Publication. 
Crosswell, L., Porter, L., \& Sanders, M. (2018). Out of Sight, Out of Mind?: Addressing Unconscious Brand Awareness in Healthcare Communication. In H. D. O'Hair, H. Chapman, \& M. Sizemore (Eds.), Risk and Health Communication in an Evolving Media Environment (pp. 55-77). New York: Routledge.

Degutis, L. C., \& Babcock-Dunning, L. (2011). Risk Communication and Media Relations. In M. J. Reilly \& D. S. Markenson. (Eds.), Health Care Emergency Management: Principles and Practice (pp. 233-270). USA: Jones \& Bartlett Learning. https://doi.org/10.1001/jama.2010.1982

Dwi, B. P. (2018). Pengetahuan Masyarakat Tentang Germas (Gerakan Masyarakat Hidup Sehat) di Dusun Ngroto $R W$ O1 Desa Pendem Kecamatan Ngariboyo Kabupaten Magetan [Universitas Muhamadiayah Ponorogo]. http://eprints.umpo.ac.id/4537/

Edgar, T., \& Volkman, J. E. (2012). Using Communication Theory for Health Promotion: Practical Guidance on Message Design and Strategy. Health Promotion Practice, 13(5), 587-590. https://doi.org/10.1177/1524839912450879

Effendy, O. U. (2017). Ilmu Komunikasi Teori dan Praktek. Bandung: Remaja Rosdakarya.

Gall, M., Gall, J., \& Borg, R. (2007). Educational Research: An Introduction (8th ed.). NY: Pearson Education.

Godinho, C. A., Alvarez, M. J., Lima, M. L., \& Schwarzer, R. (2015). Health Messages to Promote Fruit and Vegetable Consumption at Different Stages: A match-Mismatch Design. Psychology and Health, 30(12), 1410-1432. https://doi.org/10.1080/08870446.2015.1054827

Gough, A., Hunter, R. F., Ajao, O., Jurek, A., McKeown, G., Hong, J., Barrett, E., Ferguson, M., McElwee, G., McCarthy, M., \& Kee, F. (2017). Tweet for Behavior Change: Using Social Media for the Dissemination of Public Health Messages. JMIR Public Health and Surveillance, 3(1), e14. https://doi.org/10.2196/publichealth.6313

Griffiths, F., Dobermann, T., Cave, J. A. K., Thorogood, M., Johnson, S., Salamatian, K., Gomez Olive, F. X., \& Goudge, J. (2015). The Impact of Online Social Networks on Health and Health Systems: A Scoping Review and Case Studies. Policy and Internet, 7(4), 473-496. https://doi.org/10.1002/poi3.97

Guo, Y., \& Bian, J. (2019). Social Media-Based Health Interventions: Where AreWe Now? In J. Bian, Y. Guo, Z. He, \& X. Hu (Eds.), Social Web and Health Research: Benefits, Limitations, and Best Practices (pp. 15-30). Switzerland: Springer.

Harrington, N. G. (2015). Introduction to the Special Issue: Message Design in Health Communication Research. Health Communication, 30(2), 103-105. https://doi.org/10.1080/10410236.2014.974133

Haslam, K., Doucette, H., Hachey, S., MacCallum, T., Zwicker, D., Smith-Brilliant, M., \& Gilbert, R. (2019). YouTube Videos as Health Decision Aids for the Public: An Integrative Review. Canadian Journal of Dental Hygiene, 53(1), 53-66.

Huo, J., \& Turner, K. (2019). Social Media in Health Communication. In J. Bian, Y. Guo, Z. He, \& X. Hu (Eds.), Social Web and Health Research: Benefits, Limitations, and Best Practices (pp. 53-82). Switzerland: Springer.

Kauppi, S. (2015). Behavior Change and Communication: A Descriptive Literature Review of Behavior Change and Communication in Sub-Saharan Countries [Diaconia University of Applied Sciences]. https://www.theseus.fi/bitstream/handle/10024/102402/Kauppi_Susanna.pdf.pdf?sequence=1

Kemp, S. (2020). Digital 2020: Indonesia - DataReportal - Global Digital Insights. We Are Social. https://datareportal.com/reports/digital-2020-Indonesia

Kim, J. W. (2018). They Liked and Shared: Effects of Social Media Virality Metrics on Perceptions of Message Influence and Behavioral Intentions. Computers in Human Behavior, 84, 153-161. https://doi.org/10.1016/j.chb.2018.01.030

Lan, Y. L., \& Yan, Y. H. (2017). The Impact of Trust, Interaction, and Empathy in Doctor-Patient Relationship on Patient Satisfaction. Journal of Nursing and Health Studies, 02(02). 
https://doi.org/10.21767/2574-2825.100015

Laranjo, L. (2016). Social Media and Health Behavior Change. In Shabbir Syed-Abdul, E. Gabarron, \& A. Y. S. Lau (Eds.), Participatory Health Through Social Media (pp. 83-111). UK: Academic Press.

Liliweri, A. (2013). Dasar-Dasar Komunikasi Kesehatan. Yogyakarta: Pustaka Pelajar.

Madathil, K. C., Rivera-Rodriguez, A. J., Greenstein, J. S., \& Gramopadhye, A. K. (2015). Healthcare Information on YouTube: A systematic Review. Health Informatics Journal, 21(3), 173-194. https://doi.org/10.1177/1460458213512220

Millar, M. (2005). The Effects of Perceived Stress on Reactions to Messages Designed to Increase Health Behaviors. Journal of Behavioral Medicine, 28(5), 425-432. https://doi.org/10.1007/s10865-005-9009-4

Mitu, B. (2016). Health in the Digital Era: Searching Health Information Online. In V. Marinescu \& B. Mitu (Eds.), The Power of the Media in Health Communication (pp. 145-156). New York: Routledge. https://doi.org/10.4324/9781315554068

Nabi, R. L. (2015). Emotional Flow in Persuasive Health Messages Emotional Flow in Persuasive Health Messages. Health Communication, 30(2), 114-124. https://doi.org/10.1080/10410236.2014.974129

Parvanta, C. F., \& Bass, S. B. (2020). Health Communication: Strategies and Skills for a New Era. Burlington MA: Jones \& Bartlett Learning.

Passalacqua, S. (2014). Book Review. Journal Health Communication, 29, 318-320. https://doi.org/10.1080/10410236.2012.753674

Prawira W, R. Y., \& Maulida, H. (2020). Kredibilitas Komunikator Jurus Sehat Rasulullah Di Kalangan Followers Instagram @zaidulakbar (Manuscript Submitted for Publication).

Prawira W, R. Y., Mulyana, S., \& Wirakusumah, T. K. (2012). Hubungan Karakteristik Brand Ambassador Honda Spacy Helm-In dengan Tahapan Keputusan Pembelian Konsumen. EJurnal Mahasiswa Universitas Padjadjaran, 1(1), 1-14.

Prybutok, G. (2013). Informing Science: the International Journal of an Emerging Transdiscipline YouTube: An Effective Web 2.0 Informing Channel for Health Education to Prevent STDs. Informing Science: The International Journal of an Emerging Transdiscipline, 16.

Rus, H. M., \& Cameron, L. D. (2016). Health Communication in Social Media: Message Features Predicting User Engagement on Diabetes-Related Facebook Pages. Annals of Behavioral Medicine, 50(5), 678-689. https://doi.org/10.1007/s12160-016-9793-9

Schiavo, R. (2007). Health Communication: From Theory to Practice. CA: Jossey-Bass.

Schroeder, R., \& Fry, J. (2007). Social Science Approaches to e-Science: Framing an Agenda. Journal of Computer-Mediated Communication, 12(2), 563-582. https://doi.org/10.1111/j.1083-6101.2007.00338.x

Simon Kemp. (2011, December 13). Social, Digital and Mobile in Indonesia - We Are Social. We Are Social. https://wearesocial.com/blog/2011/12/social-digital-mobile-indonesia\#

Sommariva, S., Vamos, C., Mantzarlis, A., Uyên-Loan Đào, L., \& Tyson, D. M. (2018). Spreading the (Fake) News: Exploring Health Messages on Social Media and the Implications for Health Professionals Using a Case Study. American Journal of Health Education, 00(00), 1-10. https://doi.org/10.1080/19325037.2018.1473178

Suryani, D., Nurdjanah, E. P., Yogatama, Y., \& Jumadil, M. (2019). Membudayakan Hidup Sehat Melalui Gerakan Masyarakat Hidup Sehat (Germas) Di Dusun Mendang Iii, Jambu Dan Jrakah Kecamatan, Tanjungsari, Gunungkidul. Jurnal Pemberdayaan: Publikasi Hasil Pengabdian Kepada Masyarakat, 2(1), 65. https://doi.org/10.12928/jp.v2i1.486

Syed-Abdul, S., Gabarron, E., Lau4, A. Y. S., \& Househ, M. (2016). An Introduction to Participatory Health Through Social Media. In Shabbir Syed-Abdul, E. Gabarron, \& A. Y. S. Lau (Eds.), Participatory Health Through Social Media (pp. 1-10). UK: Academic Press.

Tedy, Fadly, \& R, R. (2018). Hubungan Program Germas Terhadap Kebiasaan Hidup Masyarakat Yang Telah Dan Belum Mendapatkan Sosialisasi Di Wilayahkerja Puskesmas Kecamatan 
Sukarame Palembang. Jurnal Kesehatan Palembang, 13(1), 54-60.

Thomas, R. K. (2006). Health Communication. USA: Springer.

Thompson, S. R. (2014). The Essential Guide to Public Health and Health Promotion -. London: Routledge.

U.S. Department of Health and HumanServices. (2009). The Surgeon General's Call to Action to Promote Healthy Homes. In The Surgeon General's Call to Action to Promote Healthy Homes. U.S. Department of Health and Human Services, Office of the Surgeon General. http://www.ncbi.nlm.nih.gov/pubmed/20669408

Viswanath, K., \& Emmons, K. M. (2006). Message Effects and Social Determinants of Health: Its Application to Cancer Disparities. Journal of Communication, 56(SUPPL.). https://doi.org/10.1111/j.1460-2466.2006.00292.x

Westerwick, A., Johnson, B. K., \& Knobloch-Westerwick, S. (2017). Change Your Ways: Fostering Health Attitudes Toward Change Through Selective Exposure to Online Health Messages. Health Communication, 32(5), 639-649. https://doi.org/10.1080/10410236.2016.1160319

WHO. (2015). Effective Communications Participant Handbook. Geneva: WHO Document Production Services.

Yen, T. S. (2018). "Germas" Masih Tahap Marketing: Menanti Disrupsi Terjadi. Kompas. https://lifestyle.kompas.com/read/2018/12/02/190300320/-germas-masih-tahap-marketing-menanti-disrupsi-terjadi 